\title{
Árvores e gente no ativismo transnacional. As dimensões social e ambiental na perspectiva dos campaigners britânicos pela Floresta Amazônica
}

\author{
Andréa Zhouri \\ Departamento de Sociologia e Antropologia - UFMG
}

RESUMO: $\mathrm{O}$ ativismo transnacional constitui-se como tema ainda incipiente nas ciências sociais. A partir de uma perspectiva antropológica, este trabalho apresenta uma contribuição à compreensão dos processos políticos e culturais globais que caracterizam a contemporaneidade, centrando-se no ativismo transnacional em torno da Floresta Amazônia. A Amazônia é certamente um dos principais símbolos do ambientalismo ocidental. A maioria das ONGs transnacionais que trabalha com este tema tem sede no Reino Unido, apresentando uma atuação destacada nas campanhas do mogno, pela demarcação de terras indígenas, assim como no desenvolvimento do Forest Stewardship Council (FSC), ou Conselho de Manejo Florestal - um selo verde para produtos florestais. Este artigo analisa as diferentes trajetórias sociais e de militância dos campaigners britânicos, que os conduzem a formas distintas de engajamento com a floresta. Observa-se, então, as tensões na conjugação das dimensões social e ambiental enquanto marcas discursivas independentes das filiações organizacionais. Três principais tendências são reveladas, assim como visões globais e locais conflitantes, com conseqüências para o ambientalismo enquanto um campo de comunicação globalizado, e sobretudo para a Amazônia enquanto espaço sócioambiental.

PALAVRAS-CHAVE: ambientalismo, globalização, ONGs, Amazônia, árvores, gente. 
ANDRÉa ZHOURI. ÁrVORES E GENTE NO ATIVISMO TRANSNACIONAL

\section{Introdução}

Historicamente, antropólogos europeus e norte-americanos têm viajado a lugares como África e Amazônia para estudar os povos "nativos" - os "primitivos". Minha própria trajetória em direção à Amazônia foi conduzida numa direção inversa àquela traçada pela tradição antropológica clássica: como antropóloga brasileira, eu encontrei os meus nativos na Europa Ocidental, entre os ativistas das organizações não-governamentais que fazem campanhas pela Floresta Amazônica ${ }^{1}$.

Durante as últimas três décadas, os movimentos ambientalistas têm se constituído como uma das forças políticas mais significativas nas sociedades ocidentais, enquanto as organizações ambientalistas são normalmente analisadas no contexto dos assim chamados "novos movimentos sociais"2. Seja na perspectiva americana da mobilização de recursos (resource mobilization) ou na vertente européia que privilegia a construção de identidades coletivas, as organizações e movimentos são geralmente discutidos em termos de suas ideologias, estruturas organizacionais, estilos políticos, transparência (accountability), desempenho, profissionalismo, bases de apoio e ainda em relação às motivações de seus membros e partidários. Assim, as teorias que circunscrevem o campo dos movimentos sociais, sobretudo na perspectiva da ciência política, parecem influenciar fortemente os estudos ainda pioneiros sobre a formação de redes transnacionais de ativistas (Keck \& Sikkink, 1999). Embora os estudos sinalizem em direção à contribuição dos novos movimentos sociais para a abordagem dos aspectos qualitativos da existência na esfera política, pouca relevância tem sido dada às experiências de vida concretas de ativistas no interior das organizações e redes sociais e ambientalistas transnacionais. Quem são os campaigners das Organizações Não-Governamentais (ONGs) ${ }^{3}$ ? Como relacionam suas trajetórias pessoais às questões das quais se ocupam e às organizações para as quais trabalham? Como articulam uma visão de mundo e dos processos globais? Quais as implicações de suas histórias de vida para as práticas das ONGs? Estas são algumas das questões de fundo 
Revista de Antropologia, São Paulo, USP, 2001, v. 44 nº 1.

que orientam a presente discussão que, centrada numa perspectiva antropológica, pretende oferecer uma contribuição a um campo de estudos ainda incipiente sobre os processos políticos e culturais transnacionais.

Enquanto as ONGs e as redes transnacionais despontam como atores políticos significativos na contemporaneidade, a Amazônia apresentase como um dos principais símbolos do ambientalismo global e do ativismo transnacional. Como tal, ela é constituída por lugares e espaços políticos, sociais e históricos, cujas imagens são altamente contestadas por diferentes grupos, não somente nos níveis local e nacional, mas sobretudo no universo global. Assim, para um seringueiro, um caboclo ribeirinho ou um índio, os diferentes ecossistemas da Amazônia podem representar, num nível localizado, os recursos necessários para a sobrevivência cotidiana. Para um general brasileiro, a Amazônia é uma fronteira a ser defendida. Para um cientista, lá estão os ecossistemas de maior biodiversidade a serem investigados. Enquanto uma empresa multinacional pode ver na floresta amazônica a madeira de lei a ser exportada, um antropólogo vê a diversidade cultural; viajantes buscam aventura e prazer junto à natureza, ao passo que um ambientalista pode valorizar a floresta como um recurso natural vital e o lar de pessoas cujo modo de vida encontra-se ameaçado pelo capital transnacional.

Conseqüentemente, atravessando as fronteiras culturais e os limites dos Estados-Nação, a Amazônia surge como um espaço político transnacional através do qual questões e dilemas se constituem. Entretanto, ao mesmo tempo em que expressa conflitos entre diferentes grupos nas esferas local, nacional e global, ela é também um território no qual uma comunidade imaginada transnacional (Anderson, 1991) é construída e contestada através da formação de alianças, como, por exemplo, aquelas estabelecidas entre as várias ONGs transnacionais, e entre ONGs e habitantes da floresta. É nesse sentido que a Amazônia pode ser entendida como um dos símbolos mais fortes do ambientalismo contemporâneo e tema da presente discussão. 
ANDRÉA Zhouri. ÁRVORES E GENTE NO ATIVISMO TRANSNACIONAL

Comentaristas de diferentes vertentes intelectuais têm discutido os processos de globalização, não somente em termos econômicos, mas sobretudo em seus aspectos culturais e sociais (Robertson, 1992; Friedman, 1994; Featherstone, 1990; Harvey, 1989; Gupta \& Ferguson, 1992; Giddens, 1995). A idéia de uma crise ambiental global, o desenvolvimento de uma consciência a este respeito, bem como as respostas que a crise teria suscitado nas últimas décadas do século XX são aspectos apontados por tais correntes e analisados mais detidamente por autores que tratam especificamente do tema ambiental (Beck, 1992; Milton, 1996; Lash et al., 1996; Redclift \& Benton, 1994). Não obstante, em contraste com a pesquisa na qual este artigo se baseia (Zhouri, 1998), em geral a maneira como os campaigners das ONGs, particularmente as ambientalistas, expressam e experimentam tais processos globais não tem sido considerada substantivamente.

Num sentido mais amplo, por exemplo, Giddens (1995: 4) refere-se à globalização como ação à distância. Sua intensificação em anos recentes é relacionada à emergência dos meios de comunicação instantânea global e aos transportes de massa. Assim, a partir de um novo escopo de tempo e espaço, novas formas de ação (agency) e práticas políticas emergem, questionando e redefinindo os limites dos Estados-Nação. A compressão tempo-espaço juntamente com um aspecto de "desafeto pelos mecanismos políticos ortodoxos" (: 7) dão origem a agentes transnacionais em movimentos e organizações ambientalistas, feministas, étnicas e pacifistas. Embora global em escopo, tais organizações e movimentos expressam contudo manifestações ainda particulares circunscritas a legados históricos, nacionais e culturais específicos. É nesse contexto que se torna pertinente falar em organizações e movimentos transnacionais, pois expressam um nível de integração que recorta transnversalmente os níveis local, regional, nacional e internacional, sem contudo englobá-los num círculo concêntrico, nem dissolvê-los, eliminando-os por completo (Lins Ribeiro, 2000).

Nesse sentido, a Amazônia brasileira está no cerne das ações de diversos grupos em todo o mundo, sobretudo no continente europeu. 
Revista de Antropologia, São Paulo, USP, 2001, v. 44 nº 1.

As organizações transnacionais mais atuantes têm sede na Grã-Bretanha, como a Worldwide Fund For Nature (WWF), a Friends of the Earth (FoE) e o Greenpeace na área ambiental, a Oxford Committee for Famine Relief (OXFAM) na área social, a Survival International na questão dos direitos indígenas, a Anistia Internacional no tema dos direitos humanos, e finalmente a World Rainforest Movement (WRM) - a principal rede mundial de ONGs relacionada à floresta tropical. Questões relevantes podem ser suscitadas tendo em vista a atuação dos grupos ambientalistas transnacionais na Amazônia. Por exemplo, é importante considerar as especificidades do relacionamento entre os atores globais, nacionais e locais, assim como as possíveis relações de poder e conflitos resultantes de suas ações conjuntas. Nos limites deste artigo, cabe lembrar que, numa perspectiva nacionalista, as ONGs transnacionais são vistas com suspeita por diversos setores no Brasil, sobretudo pelos militares e elites econômicas e políticas locais. Acusações de eco-imperialismo e romantismo, assim como suspeitas de que as ONGs agem em nome dos interesses econômicos dos países desenvolvidos, são imagens comuns construídas freqüentemente pelos setores nacionalistas da sociedade brasileira ${ }^{4}$. Os campaigners têm consciência de como são percebidos por esses grupos e, assim, as alegações brasileiras de imperialismo ecológico e romantismo aparecem como as principais referências contra as quais seus discursos são produzidos no contexto das entrevistas realizadas durante minha pesquisa entre 1994 e $1998^{5}$.

Nas páginas seguintes, apresentarei uma análise das principais tendências no "campo amazônico-britânico das ONGs", baseando-me nos depoimentos dos campaigners. Procurarei especificar os elementos discursivos que definem as diferentes perspectivas - isto é, as regularidades que compõem cada tendência - focalizando as trajetórias pessoais e sociais que levaram os campaigners a se relacionarem com a Amazônia, produzindo, assim, uma forma particular de discurso e engajamento com a floresta.

As tensões constitutivas da Amazônia enquanto um campo de comunicação e disputa entre diferentes posições abrangendo o Brasil, a 
ANDRÉA Zhouri. ÁRVORES E GENTE NO ATIVISMO TRANSNACIONAL

Grã-Bretanha e a esfera transnacional podem ser igualmente observadas entre os campaigners. Seguindo o relatório Bruntdland e seu conceitochave de "desenvolvimento sustentável" nos anos 80 - reforçado ainda pelo Earth Summit, em 1992 -, uma política de incorporação das dimensões social e econômica junto à arena ambiental, assim como uma consideração ambiental na agenda econômica, vem ocorrendo através de várias iniciativas governamentais e não-governamentais. Um caso em questão é o fato de que, em termos de cooperação transnacional entre ONGs, questões como desigualdade social, comércio e dívidas internacionais chamaram a atenção de grupos ambientalistas do hemisfério "norte", e têm sublinhado suas campanhas florestais e seu relacionamento com as ONGs do "sul"7. Contudo, a articulação entre o "social" e o "ambiental” permanece ainda instável e remete a disputas que envolvem posições sociais e políticas distintas, uma vez que o próprio conceito de "desenvolvimento sustentável" compreende significados imprecisos, cambiantes e controversos ao relançar a "ideologia do desenvolvimento" no contexto da atual fase da globalização ${ }^{8}$. Ocorre, então, que a imbricação entre preocupações com biodiversidade e justiça social é constitutiva dos discursos dos campaigners sobre a Amazônia. No entanto, as configurações discursivas assumem formas diversas e enfatizam significados diferentes e tensionados a partir das trajetórias pessoais e sociais específicas dos campaigners. Ou seja, ênfase na biodiversidade, de um lado, ou no aspecto social, de outro, remete a trajetórias de vida e militância para além das nuanças ideológicas de cada organização.

Com o propósito de uma visualização gráfica, delineio três tendências entre os campaigners britânicos para com a Amazônia: "Árvores", "Gente" e "Árvores e Gente". "Árvores" representam aqueles campaigners que enfatizam preocupações com meio ambiente/biodiversidade, "Gente" corresponde àqueles que enfatizam questões de desenvolvimento/ justiça social, enquanto "Árvores e Gente” compõem a síntese das duas tendências anteriores. As palavras "árvores" e "gente" são utilizadas em um sentido metafórico. De um lado, encapsulando preocupações da ordem da conservação, preservação, proteção e uso sustentável 
Revista de Antropologia, São Paulo, USP, 2001, v. 44 nº 1.

do meio ambiente e, de outro, questões relativas à justiça social, desenvolvimento e direitos humanos. Além disso, cabe notar que falo de tendências predominantes entre campaigners para enfatizar a natureza heurística e flexível de tais categorias e modos de classificação, para além das evidentes diferenças entre as ONGs e a irredutível complexidade das questões em jogo. Conseqüentemente, a idéia de uma tendência entre campaigners sugere que, de fato, há uma grande interação, comunicação e tensão entre eles, uma vez que, em termos gerais, a maioria tem consciência do entrelaçamento entre questões ambientais e sociais e esforça-se por conjugá-las nas atividades de campanha.

\section{Diferentes raízes/rotas, diferentes visões/ações}

As tendências "Árvores", "Árvores e Gente" e "Gente" - e as tensões entre o social e o ambiental que elas sugerem - serão aqui analisadas vis à vis às experiências de deslocamento dos entrevistados, o desenvolvimento de sua consciência política, seu envolvimento com a Amazônia e suas justificativas para a atividade de campanha.

Um elemento comum a ser destacado entre os entrevistados é o fato de todos apresentarem uma experiência de viagem e deslocamento como parte de seus engajamentos políticos. Para muitos, a "desterritorialização" começou cedo ainda, como parte de suas experiências familiares. Em alguns casos, por exemplo, um dos pais era diplomata ou militar, ou funcionário de uma companhia britânica na África e na América Latina, e ainda houve aqueles que se deslocaram no interior da própria Inglaterra, ou da Escócia para Inglaterra, concebendo-se, assim, como imigrantes ou até mesmo como "internacionalistas". Não obstante, esses viajantes contemporâneos diferem dos viajantes britânicos do século passado - burocratas coloniais, exploradores, geógrafos, cientistas e antropólogos - que ajudaram a instalar no imaginário britânico uma fascinação pela natureza e pelas culturas "exóticas", enquanto contribuíam para a expansão do império britânico e do 
ANDRÉA Zhouri. ÁRVORES E GENTE NO ATIVISMO TRANSNACIONAL

capitalismo9. Diferentemente desses representantes dos interesses de entidades nacionais, os campaigners das ONGs - enquanto atores políticos transnacionais - representam um novo relacionamento entre cidadania e Estados-Nação, colocando os últimos em questão ao agirem e intervirem de maneiras que ultrapassam as suas fronteiras ${ }^{10}$.

É lugar comum hoje em dia a afirmação de que, devido à comunicação global instantânea e os transportes de massa, as distâncias tornaramse menores, o tempo e o espaço foram comprimidos e os contatos entre diferentes culturas agora moldam as experiências pessoais do mundo de uma maneira global. Naturalmente, tais experiências globais exigem algumas pré-condições na forma de recursos financeiros, acesso a novas tecnologias e habilidades lingüísticas. A rigor, a maioria dos ambientalistas e defensores dos direitos humanos compartilha tais pré-requisitos para a experiência do global. Assim, áreas remotas tornaram-se mais próximas e interligadas, assim como o "exótico" tornou-se familiar. Entretanto, isso não implica que tais ativistas possuam todos um entendimento homogêneo do mundo. Tampouco significa afirmar que a intensificação do contato produz uma melhor compreensão ou uma melhor comunicação com o "Outro". Apesar de compartilharem princípios básicos, são diferentes as motivações para viajar, os percursos, as interações com a alteridade e as formas de engajamento político. Segue, como conseqüência, que atores globais específicos têm experiências e imagens distintas, por exemplo, da Floresta Amazônica, criando e reproduzindo significados correlatos no interior do universo das ONGs sediadas no Reino Unido.

"Estar lá", ter experiência prática e direta "do local", é um dos componentes mais enfatizados em todos os depoimentos ${ }^{11}$. Contudo, apesar de o "estar lá" conferir certa autoridade ao ator político que embarca numa campanha globalizada, o contato direto com a Amazônia pode levar à criação de práticas discursivas diferenciadas e experiências políticas diversas. Tais diferenças são reveladas e agrupadas nas três tendências identificadas entre os campaigners. 
Revista de Antropologia, São Paulo, USP, 2001, v. 44 nº 1.

\section{Árvores}

Para o grupo de entrevistados com interesses voltados para a biodiversidade e o meio ambiente em sentido estrito, "estar lá" assume um significado político-científico. É a prática da pesquisa que sustenta suas visões e ações em nível profissional. Os campaigners que exemplificam esta tendência são encontrados nas principais organizações ambientalistas, a saber: Worldwide Fund for Nature (WWF), Friends of the Earth (FoE) e Greenpeace, independentemente das orientações políticas e organizacionais específicas de cada grupo.

Com a crescente profissionalização das $\mathrm{ONG}$ s desde os anos 80, observa-se uma inclinação no sentido do recrutamento de campaigners florestais especialistas em silvicultura (engenheiros florestais, por exemplo), ecologia, biologia, geografia, botânica e áreas afins. Um rápido perfil dos campaigners agrupados nesta tendência revela que a maioria deles corresponde a uma geração jovem, geralmente por volta dos trinta anos, com treinamento acadêmico nas áreas acima mencionadas. Apesar de terem viajado por regiões florestais da África e da América Latina como parte de suas atividades acadêmicas - "trabalho de campo" em florestas tropicais -, eles geralmente nunca viveram em países do "terceiro mundo" ou em regiões de floresta tropical.

De modo significativo, suas qualificações profissionais eram o primeiro aspecto mencionado quando eu indagava: "fale-me sobre você". Isso foi observado, de modo geral, nos depoimentos dos campaigners que trabalhavam para o Greenpeace, Friends of the Earth e também para o WWF por ocasião da pesquisa. Os trechos abaixo exemplificam este dado ${ }^{12}$ :

Eu comecei fazendo uma graduação em ecologia, na Universidade de Leeds (...) e sempre estive envolvida em trabalhos com ONGs (...) há uma organização chamada British Trust for Conservation Volunteers onde você passa finais de semana, ou uma semana no campo ajudando - trabalbando em questões de conservaşão - seja na construção de um muro de pedra ou trabalhando na floresta - trabalho de campo mesmo. E, desde os tempos de colégio que estou 
Andréa Zhouri. Árvores E GENTE NO ATIVISMO TRANSNACIONAL

envolvida com projetos deste tipo (...). Eu também me interessava por biologia e geografia. Mas eu não estava interessada na ciência pura, mesmo. Eu estava interessada na ligação entre ela e o que estava acontecendo hoje, o que estava acontecendo com o meio ambiente (...) [para] aprender algo que fosse relevante para os problemas ambientais que eu podia ver à minha volta. Então, eventualmente, eu queria trabalhar em um emprego ou posição onde minhas decisões (...) tivessem um efeito direto no sentido de parar com aqueles abusos ambientais. (campaigner do Greenpeace, mulher, em torno de 30 anos)

Ímpeto semelhante pode ser observado no depoimento de uma campaigner do FoE:

Eu fui criada ao redor do mundo porque meu pai sempre se mudava. Eu me graduei em geografia, e estudei políticas verdes e questões ambientais. Então eu decidi, quando ainda era uma estudante, que queria trabalhar para o Friends of the Earth. Eu me formei em 1990 e vim direto para o Friends of the Earth e trabalhei na equipe de floresta tropical como voluntária (...). A geografia sempre me interessou: diferentes partes do mundo. Então, eu estava bem ciente de que ter um emprego não era apenas ganhar dinheiro e ir para casa no fim do dia e me esquecer do trabalho. Eu sempre quis fazer algo que eu sentisse que eu estava muito, muito envolvida pessoalmente e não apenas profissionalmente. Minha maior influência foi meu tutor na universidade. Eu o detestava [risos]. É muito estranho que tenha sido ele quem tenha me influenciado a seguir este caminho, mas foi. Ele veio com essa coisa de marxismo, ele era bem de esquerda e costumava expressar suas próprias concepções políticas para nós. Algo que nós não gostávamos. Nós éramos, por assim dizer, bem apolíticos. Eu realmente achava o lado geográfico da coisa: sistemas climáticos, e como a polnição afetava os sistemas meteorológicos e o clima (...) isto realmente me interessava. Nós temos tanta influência em como o mundo, o mundo natural, se desenvolve e nos seus danos (...) eu apenas decidi que era isso que en queria fazer. (campaigner do Friends of the Earth, mulher, em torno de 20 anos)

E ainda no testemunho de outro campaigner, agora do WWF:

Eu estou no WWF há oito anos. Eu vim para o WWF direto da universidade. Eu fiz o meu mestrado em ciências florestais, em Oxford, na área de Silvicultura e Usos da Terra. E então, fui para Forestry Conservation [setor de conservação florestal], e inicialmente eu estava trabalhando nos 
Revista de Antropologia, São Paulo, USP, 2001, v. 44 nº 1.

projetos de campo, particularmente na África Ocidental, na Nigéria e em Camarões. E, de modo crescente, eu venho trabalhando no desenvolvimento de políticas, diretrizes florestais relacionadas a governos e indústrias. (homem, em torno de 30 anos)

Nesses casos, é a possibilidade de praticar uma "ciência aplicada" e influenciar as decisões políticas relacionadas às questões florestais que constituem a base ou a força motivadora no bojo dos engajamentos. Estes campaigners iniciaram suas carreiras profissionais numa época em que o ativismo (campaigning) já estava ocorrendo num âmbito profissionalizado pelas ONGs. Apesar de atuarem em campanhas pela Amazônia, a importância que os entrevistados atribuem ao "estar lá" não necessariamente os conduziu a esta região. Para esse grupo específico, é a África o lugar mencionado como primeiro contato com uma floresta. Isso pode ser observado na citação anterior do campaigner do WWF, bem como nos casos a seguir:

Eu já estive na África, mas não em florestas tropicais. Mas, obviamente, eu adoraria ir. Seria interessante. (campaigner do FoE)

Eu tenho curtido viajar sozinha e com amigos, simplesmente porque me interesso muito por tudo que está acontecendo na vida ao redor do mundo. Sabe, sou curiosa - particularmente com a África, eu tinha muito interesse. Eu tenho essa fascinação pela África. Chegar a vários lugares e à vida selvagem, à natureza na África. E eu senti que era muito importante estar (...) ver esses lugares, visitar e obter uma bagagem de conhecimento e experiência. Eu tenho viajado muito com o Greenpeace também. Mas é bom viajar e estar envolvido em algo no campo. (campaigner do Greenpeace)

Parece que a África (e a Ásia, e em menor grau a América Latina) tem um papel importante como um topos na imaginação cultural britânica. Tais lugares são, igualmente, um tropo na literatura ocidental e nos textos coloniais, particularmente no gênero de viagens, do qual o exemplo clássico é Heart of Darkness, de Joseph Conrad ${ }^{13}$. O interesse pelas culturas exóticas e pela vida selvagem - dois conceitos interligados - fundamentam ambas as práticas, imperialista e ambientalista. Alguns dos entrevistados foram até mesmo explícitos em suas declarações sobre 
ANDRÉA Zhouri. ÁRVORES E GENTE NO ATIVISMO TRANSNACIONAL

tal conexão, colocando-se até mesmo como agentes reparadores do "mal causado pelo Reino Unido às suas ex-colônias". Entretanto, para esse grupo de campaigners em particular, o interesse pelas viagens relaciona-se menos à expressão e reparação da culpa colonial, mas se define sobretudo por uma experiência que um campaigner do Greenpeace definiu como contendo "um componente científico, um componente de aventura, e um componente comunitário". Seguindo essa ordem, no entanto, parece que a aventura é o componente que sublinha a possibilidade do exercício da ciência em sentido prático, uma vez que a dimensão comunitária aparece apenas como uma conseqüência dos outros dois aspectos da experiência. Tudo isso tem uma influência direta em como o Brasil e a Amazônia são percebidos nos horizontes da tendência "Árvores" - a ênfase maior recai sobre a preservação da "biodiversidade". Quando os "povos da floresta" são considerados - geralmente os povos indígenas -, eles o são em relação à preservação da "mata", em sentido estrito.

Apesar de envolvidos na campanha contra o comércio de mogno da Amazônia desde o início dos anos 90, a maioria dos campaigners desta tendência havia realizado breves viagens à Amazônia, normalmente para contatos com as organizações locais. Eles não apresentavam, portanto, qualquer interesse ou laço pessoal com aquela região do globo para além das visitas profissionais. Expressando uma "consciência do globo" (Robertson, 1992), os campaigners articulam as questões florestais nos horizontes dos impactos das práticas econômicas e estruturas políticas globalizadas sobre as áreas florestais. Assim, tal consciência da globalização associada às formações sociais e profissionais específicas dos campaigners conduz necessariamente a um entendimento e conceitualização das florestas de uma maneira técnica e abstrata. Resulta daí que realidades históricas, culturais e sociais específicas são predominantemente agrupadas e subsumidas em padrões ou modelos gerais de florestas. Nesse sentido, as realidades constitutivas da Floresta Amazônica aparecem como equivalentes àquelas de outras florestas tropicais do globo, como as da Malásia e Indonésia. 
Revista de Antropologia, São Paulo, USP, 2001, v. 44 nº 1.

Conseqüentemente, o contato que os campaigners de "Árvores" têm com as "comunidades locais" - assim genericamente referidas - constituise, sobretudo, de um contato profissional com as ONGs "locais", as quais têm um papel crucial enquanto fornecedoras de informações para as organizações sediadas no Reino Unido. Tal aspecto pode ser ilustrado com o seguinte depoimento de uma campaigner do Friends of the Earth, ao responder à pergunta sobre os possíveis projetos que sua organização desenvolvia no Brasil:

Temos um forte vínculo com a FoE Internacional na Amazônia. Quero dizer, com o grupo FoE da Amazônia. Há uma organização conhecida como GTA que é uma rede de mais ou menos 200 ONGs brasileiras. Eles nos escreveram e disseram: por favor, vocês poderiam trabalhar nessa situação que é realmente terrível, precisamos de sua ajuda (...). Mas existem muitos outros grupos como esse. A sócioambiental (...) alguma coisa assim [o ISA (Instituto SócioAmbiental), com sedes em Brasília e São Paulo]. Eles estão trabalhando para os mesmos fins, na verdade. Eles estão fazendo lobby no seu governo para tentar parar o corte ilegal de mogno dentro das reservas indígenas. Eles estão também cuidando das questões de direitos humanos, os índios sendo assassinados e corrompidos. (campaigner do Friends of the Earth)

A prioridade da agenda é certamente o comércio do mogno. Apesar de a Amazônia ser conceituada em relação a seus diferentes ecossistemas, as campanhas concentram-se predominantemente nas florestas de terra firme, uma vez que estas podem ser mais facilmente enquadradas nas mensagens para o público britânico consumidor. Além disso, como reflexo da crescente preocupação internacional com equidade social e direitos humanos, a defesa das "populações locais" nos discursos dos campaigners refere-se, grosso modo, a uma parcela específica da população amazônica - os povos indígenas. Como afirma também um campaigner do Greenpeace:

Nós temos um escritório do Greenpeace no Rio, agora, e nós nos aliamos muito fortemente a eles no sentido de, enquanto representantes do Greenpeace Internacional, construirmos estratégias internacionais em conjunto para que a campanha tenha sucesso. Nós temos um grupo de ONGs muito bom, 
ANDRÉa ZHOURI. ÁrVORES E GENTE NO ATIVISMO TRANSNACIONAL

muito forte neste país, trabalhando na questão do mogno. Nós vamos demandar uma moratória ao comércio de mogno brasileiro com base nas informações que recebemos do Brasil, de pessoas das bases: comunidades indígenas e grupos ambientais, assim como o Greenpeace, que informam que a maioria do mogno lá é retirado ilegalmente de reservas indígenas.

No entanto, apesar da referência aos povos indígenas, estes aparecem no discurso como um argumento secundário, porém estrategicamente legitimador do alvo prioritário da campanha, como faz crer na passagem em que discorre sobre as estratégias do Greenpeace para a campanha do mogno:

O primeiro estágio é construir uma consciência do problema. Nós fazemos isso através do envio de correspondências e também através da cobertura da mídia, vendendo a história aos jornais, televisão e rádio. Para espalhar a mensagem, a fim de educar as pessoas sobre a existência do problema. Uma vez que as pessoas tenham sido instruídas a respeito da existência do problema, e então eles podem usar [o argumento] de que as pessoas têm fome ou que eles querem fažer algo, então você pode usar aquele "painel gente", por assim dizer, para ter um efeito onde combinar. (campaigner do Greenpeace)

Em outros momentos, "populações locais" - como uma abstração genérica - podem ainda referir-se indiscriminadamente às ONGs brasileiras e entidades de base, quando, por exemplo, os campaigners justificam que suas campanhas surgiram a partir de demandas locais. Para a tendência “Árvores”, os vínculos com a Amazônia são promovidos, em geral, através das ONGs profissionais e bem-estruturadas. $\mathrm{O}$ fato de a Amazônia ser um lugar imaginado em termos técnicos - sobretudo através de perspectivas florestais ou silviculturais - aumenta a distância entre ONGs globais e comunidades locais. A linguagem falada pelos ambientalistas globais apresenta uma configuração formada pela língua inglesa conjugada a uma terminologia técnica, aumentando sobremaneira a necessidade de intermediários nacionais com as mesmas habilidades. WWF, Greenpeace e Friends of the Earth, cada qual tem suas próprias filiais ou escritórios no Brasil. Como mencionado acima e reforçado pelo campaigner do Friends of the Earth: 
Revista de Antropologia, São Paulo, USP, 2001, v. 44 nº 1.

Nós não podemos nos dar ao luxo de apoiar um grupo que acabou de se formar e quer trabalhar na floresta. Sabe, nós não temos o tempo, o dinheiro e os recursos. Nós estamos trabalhando por nós mesmos. Mas, se há um grupo trabalhando assim como nós, e pode nos proporcionar boas informações, nós trabalharemos com eles. Como trabalhamos com a Survival International on o Greenpeace. É mútuo, entende?

Por certo, o desenvolvimento de um projeto cooperativo demanda um mínimo de afinidades entre os parceiros, ou seja, o compartilhamento de princípios e objetivos comuns. Entretanto, a "mutualidade", que na passagem acima assume um significado de relacionamento igualitário, parece ser definida e somente entendida em relação a outras organizações transnacionais com padrão ou perfil semelhante aos das entidades sediadas no Reino Unido, tais como o Greenpeace e a Survival International. Contudo, quando se considera o contexto amazônico, a expectativa ou exigência de um tal perfil sugere algumas indagações. A prioridade das ONGs globais implica a parceria com as ONGs profissionais mais estruturadas - aquelas com qualificações técnicas, habilidades lingüísticas e computacionais -, capazes de conduzir pesquisas e fornecer informações. Os problemas e contextos tipicamente locais da Amazônia exigem uma tradução para a esfera global. Assim, o relacionamento com as entidades de base ou com as comunidades locais passa a ser mediado pelas ONGs profissionais brasileiras, a maioria delas sediadas no sul do país e ainda dependentes dos recursos financeiros das entidades internacionais. Tal dinâmica de relacionamento suscita uma indagação: em que medida as ONGs brasileiras conseguem trabalhar as necessidades das agendas locais e ao mesmo tempo responder à crescente demanda por informações "das bases" (from people on the ground) vindas das ONGs globais? Como enuncia um campaigner do Greenpeace:

A força da campanha [do mogno] é o fato de ela ser internacional. Ela tem essas fortes conexões internacionais. Então, por exemplo, para que a gente possa conduzir campanhas contra o mogno no Reino Unido, nós precisamos de informações específicas do Brasil. Tipos de informações diferentes e espe- 
ANDRÉa ZHOURI. ÁrVORES E GENTE NO ATIVISMO TRANSNACIONAL

cíficas. Nós precisamos delas de uma forma que possamos utilizá-las. Não faz sentido apresentar (...) produzir algo que não podemos usar, on que não seja apropriado ou algo assim. Então, é importante a gente sentar e conversar sobre como estruturar uma campanha internacional; o que necessitamos do Brasil; conversar sobre o momento, o ritmo, ou quando as coisas vão acontecer ou como podemos ajudá-los.

A ênfase discursiva parece recair sobre aquilo que "nós" - campaigners britânicos - precisamos. Obviamente, isto é justificável no contexto das estratégias para uma campanha internacional. Os governos, sobretudo o brasileiro, são vulneráveis e suscetíveis às pressões internacionais. Contudo, há determinados limites para uma atuação legítima das ONGs globais, a fim de não suscitarem sensibilidades e ultrapassarem as soberanias dos Estados-Nação. A campanha do mogno é dirigida contra o comércio internacional - a importação do mogno brasileiro pela GrãBretanha e pelos Estados Unidos - e é assim que os campaigners britânicos podem, confortável e legitimamente, conduzir suas campanhas para a preservação da floresta sem interferirem nos "assuntos domésticos". Porém, cabe refletir sobre a extensão do investimento das ONGs brasileiras, em tempo e recursos, no sentido do atendimento às demandas das ONGs globais vis à vis sua atuação em face das prioridades locais e regionais - tais como a própria questão da madeira de lei (que é consumida predominantemente no mercado interno), a reforma agrária e o avanço da indústria agrícola, dentre outros temas pertinentes à Amazônia. Cabe indagar, por exemplo, em que medida as ONGs brasileiras podem ser consideradas "globais" e o papel que desempenham na formulação e encaminhamento das estratégias e campanhas globais.

\section{Árvores e Gente}

Outra tendência entre ONGs e campaigners, igualmente envolvidos na campanha do mogno, parece articular as "questões florestais" de uma maneira política menos técnica. Os campaigners de "Árvores e Gente" compõem uma geração mais antiga - na faixa dos quarenta anos, de 
modo geral -, cuja formação profissional inclui treinamento em diversos campos das humanidades, seja em ciências sociais, literatura, lingüística e artes. Eles também constituem um grupo mais diversificado que o analisado na tendência “Árvores", além de estarem espalhados em organizações e redes menores como a Reforest the Earth, Gaia Foundation, e o World Rainforest Movement.

Para os campaigners agrupados nesta tendência, o envolvimento com a atividade de campanha, em geral, e suas concepções sobre a Amazônia, em particular, desenvolveram-se a partir de considerações éticas e políticas forjadas no contexto da década de 1970, sendo menos condicionados por orientações florestais técnicas. Um elemento comum entre eles, por exemplo, é a influência de publicações como The Blueprint for Survival (publicação da revista The Ecologist, que avalia o estado do planeta nas décadas 1970-1980) e os movimentos pela paz e pelos direitos das mulheres, áreas correlatas de interesse e engajamento. Além destas influências, cabe destacar ainda outro aspecto peculiar ao conjunto de "Árvores e Gente": o fato de terem vivido, em algum momento de suas vidas, em um país de "terceiro mundo" (na África e na América Latina, mas não necessariamente no Brasil). Preocupados com o "empoderamento" (empowerment) das "comunidades locais", suas atividades variam desde as chamadas "ação direta” e lobby político até mesmo ao apoio e financiamento de projetos e formação de redes de cooperação em nível local. Como na tendência "Árvores", os grupos locais de preferência são geralmente os grupos indígenas.

Dessa forma, a experiência do "estar lá" para os campaigners de "Árvores e Gente" relaciona-se, sobretudo, ao despertar de suas consciências políticas e ao início de sua militância para além do desenvolvimento de suas qualificações técnicas e profissionais. Num discurso político que contrasta com os discursos em "Árvores", uma campaigner da organização Reforest the Earth relata:

Eu me tornei politizada, acho, na medida em que fui para Camarões e fui descobrindo que havia coisas que estavam erradas, e em relação às quais deve-se tomarpartido e fazer 
ANDrÉA ZHOURI. ÁRVORES E GENTE NO ATIVISMO TRANSNACIONAL

algo a respeito. Assim, eu vou me tornando mais politizada com o passar do tempo. Porque nós temos que tomar de volta o poder que as estruturas estão nos tirando (...). Eu saí para viver em Camarões por três anos. Porque eu queria fazer algo chamado Voluntary Service Overseas (Serviço Voluntário no Estrangeiro). Eu estava interessada no desenvolvimento do terceiro mundo, sabe? Porque nós aparentávamos ser ricos e os outros pobres. E achei que seria interessante ir para um país de terceiro mundo e descobrir mais sobre isso (...). Eu descobri que havia a culpa, por assim dizer, dos paises ocidentais, o meu pais, porque esses outros países eram pobres, e descobri as relações comerciais injustas. Eu fiquei chocada ao descobrir que o colonialismo não estava morto (...). E descobrir que ainda existia racismo por aí. (mulher, em torno de 40 anos)

Ao refletir sobre a experiência pessoal num país de "terceiro mundo", a entrevistada destaca como a vivência das desigualdades econômicas e sociais contribuiu para moldar sua visão de mundo e suas atitudes políticas. Daquela vivência também derivam seu entendimento sobre o entrelaçamento de questões distintas como gênero, meio ambiente e paz em nível internacional, nacional e local:

O que vai se tornando bastante evidente agora é que, com certeza, os sistemas e estruturas que existem ao redor do mundo como um todo, e vêm assim como um todo, têm roubado também o poder de seus próprios cidadãos. Então, fica bastante claro que a pobreza e a disparidade entre ricos e pobres, que estamos encontrando em nossos países, estão conectadas com o que eu bavia primeiramente notado entre o primeiro mundo (o mundo rico) e o terceiro mundo (o mundo pobre). E foi essa experiência lá e o começo do movimento ambientalista aqui, com a primeira publicação da primeira revista ecologista chamada The Blueprint for Survival, que me fez consciente das questões ambientais. (idem)

A consciência global, do "mundo-como-um-todo", na concepção de Robertson (1992), é forjada na experiência de viagem, que a torna também consciente e crítica aos processos de desigualdade no nível doméstico. Além disso, a identidade política é formulada em sua pluralidade, nos movimentos pela paz e pelos direitos da mulher, além do movimento ambientalista:

E eu fui a Greenham. Era um acampamento de mulheres pela paz. Era do lado de fora de uma das bases nucleares, bases nucleares americanas. $\mathrm{E}$ isso atraiu muitas mulheres diferentes. $\mathrm{O}$ acampamento era de mulheres pela 
paz porque tinham ocorrido alguns estupros antes, e também a agressão do exército contra homens era muito maior do que contra as mulheres. Tinha mil razões para que ele se tornasse um acampamento de mulheres. Essa foi a primeira vez em que eu fui presa. E me envolvi em bloqueios. E aquilo me deu força realmente para voltar e fazer isso aqui ao invés de simplesmente ficar por lá. (campaigner da Reforest the Earth, mulher, em torno de 40 anos)

A campaigner da Reforest the Earth é bem conhecida por suas "ações diretas" que, no caso da campanha do mogno, variam desde a "ocupação" ou invasão de escritórios de madeireiras até a prática denominada de "roubo ético" (retirada de objetos em mogno das lojas de móveis, por exemplo, e sua entrega a delegacias policiais para que sejam devolvidos aos índios brasileiros, sob a alegação de que foram roubados dos mesmos) $)^{14}$. Tais práticas são politicamente identificadas pela campaigner como uma herança da tradição gandhiana, no contexto da não-violência ativa, que propõe a utilização do próprio corpo na resistência aos abusos de poder. Para esta, assim como para outros campaigners dessa tendência, a questão central reside no "empoderamento" (empowerment) em todos os níveis daqueles “sem-poder". Assim, questões de gênero, paz, direitos humanos e meio ambiente entrelaçam-se no discurso da entrevistada, ao mesmo tempo em que são conectadas às instâncias internacional, nacional e local. Ao articular uma visão global do mundo, semelhante neste sentido aos campaigners de "Árvores", o discurso não permite vislumbrar qualquer laço mais íntimo com a região amazônica e sua gente. Nesse contexto também, as visitas à Amazônia são em geral breves contatos com ONGs locais, agências governamentais e comerciantes de mogno. Entretanto, diferentemente dos campaigners de "Árvores", as preocupações florestais são articuladas de forma menos técnica, salientando sobretudo os componentes social e político da dinâmica florestal, deixando entrever uma certa tensão entre uma perspectiva conservacionista e outra sócioambiental:

Eu viajei muito e vi e me misturei com muitas pessoas diferentes. E eu vejo que as estruturas contra as quais estamos lutando são todas parecidas, e se você não pensar no ser humano como parte do ecossistema também, se 
ANDRÉA Zhouri. ÁRVORES E GENTE NO ATIVISMO TRANSNACIONAL

você não envolver as pessoas locais, se não envolver justiça social também, se você só está pensando em conservar uma árvore ou um sapo, e você não olha para a coisa como um todo, então você não será capaz de salvá-la. (campaigner da Reforest the Earth, mulher, em torno de 40 anos)

No entanto, para uma ONG pequena como a Reforest the Earth, a ação global encontra-se sujeita a algumas limitações. A obtenção de informações oriundas da Amazônia depende do sucesso do trabalho em rede, do intercâmbio com as demais ONGs transnacionais, sobretudo as maiores como a Friends of the Earth, o WWF e o Greenpeace. Assim, os níveis de intermediação entre as comunidades locais e esse tipo de organização aumentam consideravelmente. Além das ONGs brasileiras estruturadas nacionalmente, há a intermediação dos outros grupos globais sediados no Reino Unido. Tal dificuldade é observada não somente no nível da informação técnica, mas também na comunicação comprometida pelas diferenças lingüísticas e culturais. A defasagem no conhecimento da cultura, história e idiomas locais pode implicar a construção de categorias genéricas, como "os despoderados" (disempowered) e "os povos da floresta", categorias estas que são descontextualizadas, deslocadas e esvaziadas de seus significados mais precisos. Esta é também uma forma de distanciamento das peculiaridades locais que, como na tendência anterior, permite uma prática política em termos estruturais e globais. Assim, "os pobres", "os despoderados" e as "populações locais" podem ser colocados e recolocados em diferentes contextos e disputas políticas em torno de questões globais.

Ex-campaigner da Survival International (ONG que advoga pelos direitos indígenas), outro representante da tendência "Árvores e Gente" trabalhava à época da pesquisa para o World Rainforest Movement no apoio à formação de redes locais, assim como redes locais-globais. Seu processo de deslocamento pessoal, profissional e político conduziu-o à África e à Índia antes que fosse para a Amazônia venezuelana como antropólogo. Nesse caso, a consciência política aflorou da experiência acadêmica entre os Yanomamis: 
Eu estava tentando entender como as pessoas concebem seu relacionamento com seu meio ambiente e até que ponto existe um paralelo entre o seu real relacionamento com seu meio ambiente. Foi um estudo acadêmico para um doutorado (...) e durante todo o tempo em que eu fazia esses estudos eu me tornava mais e mais preocupado com o futuro das pessoas. Porque eu podia ver que o que estava acontecendo era que esse povo estava sendo basicamente destruído através do seu contato com a sociedade venezuelana, o mundo exterior. E tínhamos consciência da depredação causada por corporações transnacionais, assim como por empresas nacionais. Toda aquela gente, e particularmente a questão dos direitos à terra, o problema da saúde, porque a área Yanomami tinha essas epidemias terríveis (...) e eu era uma testemunha do impacto dessas epidemias e percebia que aquele povo estava em crise, todos os tipos de crise (...). Eu decidi que não queria ser um acadêmico. Porque os acadêmicos não pareciam realmente se importar. Eles estavam simplesmente estudando esse processo sem intervir, e eu senti que nós tínhamos a obrigação moral de intervir nesse processo que era obviamente injusto, e certamente mortal. E então eu me converti em (...) eu continuo me tornando um ativista dos direitos humanos. (campaigner do World Rainforest Movement, homem, em torno de 40 anos)

O "estar lá" para este campaigner, em contato com a "crise" Yanomami, exacerbou sua crise existencial e profissional, trazendo-lhe dilemas éticos e morais que foram racionalizados de maneira política. Ao falar de suas experiências de viagem, a identidade política é ampliada para além do ativismo na área dos direitos humanos, salientando então a dimensão ambiental enquanto aquela que elabora uma crítica ao mundo ocidental:

Eu estava familiarizado com diferentes culturas, com diferentes maneiras de ver as coisas, com diferentes línguas, e eu era também familiarizado com o fato de que os ingleses não eram necessariamente os melhores em tudo. Sabe, existem outras sociedades, então existem respostas diferentes para as mesmas perguntas (...) e, de muitas maneiras, quando eu voltei para a Amazônia nos anos 70, eu estava procurando por sociedades alternativas para explicar o que deu errado na nossa, e porque mesmo desde os meus 16 anos eu me sentia muito alienado da civilização ocidental. Eu tinha certeza que ela era falha e errada, e eu sempre fui "um verde" no sentido de que eu sempre pensara que (...) basicamente o capitalismo é muito materialista e desgovernado a longo prazo. E ele nega muitos outros valores humanos. E então, eu estava particularmente interessado em outras sociedades humanas que talvez fossem governadas por forças diferentes. (campaigner do World Rainforest Movement, homem, em torno de 40 anos) 
ANDRÉA Zhouri. ÁRVORES E GENTE NO ATIVISMO TRANSNACIONAL

É possível identificar no testemunho acima paralelos com o depoimento da campaigner de Reforest the Earth no sentido da familiaridade com outras culturas diferentes, a visão crítica da própria sociedade e as relações de poder operantes no domínio global. Neste caso, a identidade política enquanto "um verde", pertencente a uma geração de contestadores e leitores do Blueprint for Survival nos anos 70 (a mesma literatura mencionada pela outra campaigner), é ainda combinada às leituras de relatos de viagens, como por exemplo, os relatos de Alexander von Humboldt na Amazônia. Outra semelhança entre os campaigners remete à necessidade de relacionar gente e meio ambiente. Nesse sentido, o entrevistado explicita uma crítica aos grupos conservacionistas entendidos por ele como particularmente preocupados com a destruição da mata em sentido estrito, ou seja, uma mata esvaziada do componente humano. Entretanto, tal limitação conservacionista é entendida como algo do passado e, de forma otimista, ressalta os possíveis avanços representados pela incorporação das questões sociais ao universo ambientalista como um todo. Indagado sobre suas atividades de campanha e relacionamento com as comunidades florestais ele explica:

Bem, faço todo tipo de coisas bem diferentes, porque depende do que eles precisam, ou do que eles querem, ou o que eles pedem. Então, pode ser que eles queiram conseguir o acesso à International Tropical Timber Organization [Organização Internacional para Madeiras Tropicais], porque suas terras têm sido exploradas por projetos apoiados pela ITTO. Assim, facilitamos a ida deles a encontros internacionais para fazerem lobby em nome dos seus direitos (...). Então, levantamos dinbeiro para que eles possam representar seus próprios interesses diretamente em negociações com instituições internacionais (...). Nós trabalhamos para promover seu próprio diálogo com as agências financiadoras que estão criando políticas nacionais. Assim, instituições como o Banco Mundial talvez queiram desenvolver uma política para os recursos naturais de um país (...) e as comunidades locais podem achar que eles deveriam ao menos ser consultados [risos]. E então, tentamos ajudálos a obter informações sobre o processo (...) a maioria do trabalho consiste em fornecer assistência técnica em debates sobre as políticas. (campaigner do World Rainforest Movement, homem, em torno de 40 anos)

Em contraste com a tendência “Árvores", a ênfase parece recair sobre aquilo que "eles" - as comunidades locais - necessitam. Entretanto, é 
Revista de Antropologia, São Paulo, USP, 2001, v. 44 nº 1.

possível dizer que há uma divisão de trabalho no campo da Forest Network-UK, e das ONGs em geral. Como uma organização "guardachuva" - uma organização-movimento -, a World Rainforest Movement pode abarcar outras ONGs, mas uma diferença entre esta abordagem e aquela dos grupos individuais reside no fluxo de informação em mão dupla. Assim, em contraste com o fluxo de informação em mão única, salientado na análise de "Árvores" como partindo do local para o global, as informações sobre os processos globais que afetam comunidades locais é neste caso fornecida aos grupos locais. Enquanto uma rede de ONGs, a informação circula mais freqüentemente nos sentidos localglobal, global-local, local-local, do que nas atuações individualizadas. Ao justificar a necessidade da realização de campanhas e lobby político global, o campaigner faz a seguinte referência às sensibilidades dos governos do "sul" que consideram tais ações como interferências externas:

Infelizmente, o que acontece é que, muitos desses governos tendem a prestar mais atenção em um ambientalista do norte do que em seu próprio povo. Mesmo que estejam dizendo exatamente a mesma coisa, eles notam mais (...). Alguns desses países ainda requerem muita ajuda e as agências financiadoras têm agora preocupações com o meio ambiente. E algumas se preocupam com os direitos indígenas. Os governos sentem que as entidades de campanha do norte podem interferir no montante de ajuda se eles não mostrarem boa vontade. Então, há um condicionante nos empréstimos que pode, de fato, apoiar as demandas das comunidades locais (...) então, eles usam os grupos de campanha internacionais para criar o que eles chamam de "condicionantes", para impor condições ao governo que não ouve seu próprio povo. Então, pelo fato de não se incomodarem em ouvir seu próprio povo, a coisa dá toda essa volta laboriosa. Então, o que os governos fizeram, na verdade foi, por não ouvir seu próprio povo, eles recriaram seu próprio colonialismo. Porque agora o Norte dizo que eles devem fazer. Porque eles não ouvem o seu próprio povo nos seus próprios países.(campaigner do World Rainforest Movement, homem, em torno de 40 anos)

Suas observações ilustram a relevância do apoio das ONGs do "norte" aos apelos das comunidades locais que são marginalizadas pelos governos do "sul", estes últimos governados por uma agenda hegemônica "desenvolvimentista" que, em última instância, é ela mesma montada pelas agências financeiras globais. As referências às acusações de "eco- 
ANDRÉA Zhouri. ÁRVORES E GENTE NO ATIVISMO TRANSNACIONAL

colonialismo" por parte dos governos e elites econômicas do "sul" é tópico recorrente no contexto das entrevistas realizadas com os campaigners, sublinhando a maioria de seus posicionamentos - seja ao racionalizarem e legitimarem seus engajamentos políticos pela justificativa da globalização, através de referências ao campo do comércio internacional e de outras estruturas globais de poder; seja expressando responsabilidades éticas e morais bem como solidariedade para com os "povos indígenas" e "comunidades locais". Tais colocações indicam a consciência da sensibilidade brasileira em relação às campanhas transnacionais pela Amazônia além de serem reveladoras de um certo desconforto gerado pela própria realização da pesquisa.

Finalmente, cabe destacar que entre as ONGs ambientalistas ativas no âmbito da Forest Network-UK, a tendência “Árvores e Gente" é ainda minoritária: a maioria dos campaigners tende a seguir a mesma agenda formulada pelas ONGs de "Árvores". O trabalho de cooperação em rede com os principais grupos fornece àqueles que possuem poucos recursos os meios de adquirirem informações sobre os "contextos locais", assim como a informação técnica que porventura lhes falte. Por outro lado, a agilidade e a habilidade política dos campaigners de "Árvores e Gente" contribuem para a efetivação das campanhas conduzidas pelas organizações em “Árvores”. No entanto, a falta de recursos das ONGs menores assim como o prevalecente interesse e a autonomia das ONGs maiores levaram à diluição da Forest Nework-UK em 1997, após alguns anos de intercâmbio produtivo entre diversos grupos engajados na campanha do mogno.

\section{Gente}

Os campaigners que compõem a tendência "Gente" têm uma agenda política relacionada à defesa dos direitos humanos, justiça social e "desenvolvimento social" nos países do "Terceiro Mundo". Ativos na Brazil Network, eles não se encontram particularmente envolvidos em 
Revista de Antropologia, São Paulo, USP, 2001, v. 44 nº 1.

campanhas florestais, apesar de expressarem preocupações em relação à Floresta Amazônica, sobretudo como o lugar onde as pessoas obtêm os recursos para o seu sustento. Geralmente, trabalham para organizações como a Oxfam, Cafod, Christian Aid, Amnesty International e Survival International - grupo este que mantém uma interface com as demais tendências discutidas acima.

Grosso modo, os campaigners de "Gente" sugerem certas semelhanças com aqueles da tendência “Árvores e Gente", particularmente no que tange às suas qualificações profissionais e faixa etária. Entretanto, em contraste com aqueles, apresentam uma história pessoal de envolvimentos políticos com a América Latina e o Brasil. De modo geral, muitos viveram no Brasil, falam português e revelam um entendimento significativo dos contextos domésticos e regionais, bem como de suas relações com as dinâmicas globais.

Em contraste com os campaigners de "Árvores", peritos em questões florestais, os campaigners de "Gente" podem ser definidos por outra "especialidade": são "latino-americanistas" ou "brasilianistas". Todavia, acreditam manter um diálogo com os campaigners ambientais e, apesar de uma certa crítica em relação à possível "falta de conhecimento" e compromisso daqueles para com o contexto brasileiro, os campaigners de "Gente" consideram que contribuíram politicamente para algumas mudanças no campo dos discursos ambientalistas. Nesse sentido, as perspectivas formuladas em defesa dos direitos indígenas a partir deste grupo podem aproximá-los dos demais campaigners. Entretanto, a tendência "Gente" estende suas concepções sociais para englobar também outros segmentos da floresta. Para além da defesa da demarcação de terras indígenas, uma campanha fundamental desta tendência envolve a problemática da concentração de terras no Brasil, numa perspectiva mais ampla.

Seja um defensor dos direitos indígenas, com um discurso muito próximo ao dos campaigners de "Árvores e Gente", seja um campaigner que apóia os camponeses e sem-terras na Amazônia, um ponto-chave 
ANDrÉA ZHOURI. ÁRVORES E GENTE NO ATIVISMO TRANSNACIONAL

comum entre os campaigners de "Gente" é que eles apresentam uma vivência pessoal de Brasil e de região amazônica, para além dos vínculos profissionais. Assim, juntamente ao trabalho com as ONGs brasileiras e regionais, estes campaigners também trabalham em projetos junto às comunidades locais e movimentos de base. Este é o caso, por exemplo, de uma campaigner da Survival International. No depoimento seguinte, ela reflete sobre seu envolvimento pessoal com a Amazônia e a emergência de sua consciência política ligada às questões dos direitos humanos e sociais:

Eu vivi em Roraima, precisamente onde existem muitos problemas indígenas, por 14 meses. Eu trabalhei em um projeto ambiental do INPA, em Manaus, e da Royal Geographical Society, em Londres. Então, foi uma grande experiência (...) eu ouvi falar sobre o projeto e quis retornar a América Latina. Porque eu fiz uma pesquisa acadêmica no Peru, com o povo Quechua, e eu falava um pouco de Quechua. E também, mens pais viveram na Venezuela. Então, eu sempre me senti tendo laços muito fortes com a América Latina (...) e então, quando eu era criança, eu passei cinco anos na Africa do Sul, e então eu acho que vem de lá a minha consciência do racismo e da falta de direitos humanos básicos durante o apartheid. Eu acredito que isso despertou em mim o desejo de estar mais envolvida nas lutas das minorias. (mulher, em torno de 30 anos)

A experiência de deslocamento é explicitamente relacionada ao despertar da consciência política, sobretudo em relação aos "problemas das minorias". Assim como os demais campaigners, embora indo também para "o campo" como pesquisadora, é na área das ciências humanas ou sociais que os entrevistados de "Gente" encontram seus interesses, em oposição ao campo das ciências florestais. Este também é o caso de uma ex-campaigner das organizações Oxfam e Rainforest Foundation (respectivamente, ONG social e ambiental). Pertencente ao que ela define como uma "antiga geração" de ativistas no Reino Unido, em contraste com aqueles chamados por ela de "os verdes", o envolvimento com a Amazônia foi resultado de uma experiência política na América do Sul, enquanto simpatizante de Salvador Allende, no Chile, no início dos anos 70: 
Revista de Antropologia, São Paulo, USP, 2001, v. 44 nº 1.

Em 72 en fui ao Chile. Era minha aventura estudantil. Eu queria conhecer a América Latina. Eu queria conhecer Allende, o país de Salvador Allende. Então, eu estava estudando. Eu ia fazer um doutorado no Chile. Mas eu estudei muito pouco. Eu passei mais de um ano, um ano e meio no Chile, no tempo de Allende. Eu estava lá durante o golpe de estado do Chile, certo? Setembro de 73, certo? Então eu conheci muitos brasileiros, latino-americanos de muitos países que estavam exilados lá (...). Isso [socialismo] é um tipo de romantismo novamente [risos]. Então eu decidi voltar. Eu tinha poucas opções porque tinha terminado meus estudos com o golpe de estado (...) eu voltei depois do golpe e fui trabalhar no escritório da Anistia Internacional. Eu nunca vou esquecer, porque meu primeiro trabalho, um dos meus primeiros trabalhos na Anistia, foi preparar a campanha dos dez anos de golpe no Brasil, certo? Pesquisando o número de prisioneiros políticos, torturados, desaparecidos no Brasil. (mulher, em torno de 40 anos)

O envolvimento com o Brasil decorre, pois, da experiência política inicial no Chile, a qual é explicitamente referida como uma "aventura de estudante". Tal circunstância localiza a entrevistada no contexto histórico dos engajamentos políticos de europeus em movimentos de esquerda na América Latina dos anos 70, em contraste com o fluxo “ambiental" dos anos 80 e 90. Assim, parece que o contato com o "exótico", possibilitado pela aventura do "estar lá", assume um sentido social relacionado à utopia política, ao passo que para os campaigners da tendência "Árvores", o exotismo implica, sobretudo, um significado político relacionado à biodiversidade, como uma utopia da "natureza" em termos simbólicos. A formação "socialista" é um tópico tratado com ironia, talvez refletindo o contexto de fragmentação política e ideológica dos anos 90. Ao retornar da aventura "romântico-socialista-estudantil" no Chile, após o golpe de estado, a estudante torna-se campaigner profissional e seus interesses gradualmente mudam, passando da defesa de uma política de direitos humanos para uma perspectiva mais ampla, englobando as dimensões sócioeconômicas:

Então saí [da Anistia] em 1990. Eu precisava mudar. Minhas considerações sobre o significado dos direitos humanos haviam mudado. A Anistia só trabalha com direitos políticos, certo? Políticos e sociais. E agora a questão 
ANDRÉA Zhouri. ÁRVORES E GENTE NO ATIVISMO TRANSNACIONAL

dos direitos econômicos não é trabalhada pela Anistia Internacional. E eu estava interessada nisso. Eu queria entrar em outro campo, mudar e ampliar meus conhecimentos (...) eu era uma sindicalista muito ativa. Especialmente nos anos 70 e 80 neste país, eu era uma campaigner para os sindicalistas e trabalhadores que estavam na prisão e eram perseguidos. Eu creio que foi neste tipo de percurso que eu mudei. Porque o principal problema para os sindicalistas, trabalhadores, camponeses que são perseguidos é que eles estão lutando por uma vida melhor. E uma vida melhor é - assim como ter mais liberdade política é também baseada na economia - melhor, vida melhor, entende? Um pouquinho mais de dinheiro [risos], maiores salários, mais terra. (ex-campaigner da Oxfam e Rainforest Foudation, mulher, em torno de 40 anos)

O tema do romantismo é recorrente nos relatos de sua história com a floresta amazônica, sobretudo na lembrança dos primeiros trabalhos na área social, junto a grupos indígenas no Peru:

Então, meu primeiro contato com os povos indígenas da floresta foi com aquelas duas populações. E eu passei a amá-los e respeitá-los imensamente. Amar seu país, sua terra, a floresta, as árvores, os rios, os insetos. As coisas ruins, o calor, todas as coisas ruins que a maioria dos europeus odeia, os insetos - todas essas coisas (...) - e então existe um nivel de romantismo. Eu sou ainda uma romântica totalmente incurável. Eu não tenho medo de dizer isso, mas eu também estou trabalhando nessa área, então eu tenho que tentar equilibrar meu romantismo com um grau de objetividade rigorosa também. (idem)

Ao enfatizar sua experiência pessoal das "coisas ruins da floresta", particularmente os insetos, a entrevistada procura, de um lado, desvencilhar-se de uma possível imagem brasileira que acusa os europeus preocupados com a preservação das matas de serem românticos e nunca terem estado de fato numa floresta, de outro, seu depoimento deixa entrever uma crítica implícita ao ambientalismo técnico. A experiência prática legitima seu envolvimento com os povos da Amazônia: ela "esteve lá" através de seu trabalho, e assim, apesar do enunciado "romantismo", reitera sua "autoridade" em relação ao objeto de suas campanhas.

Objetividade e profissionalismo são os atributos mais valorizados para a prática dos campaigners profissionais em meio à proliferação de ONGs, sobretudo a partir da UNCED-92. Tal concepção é reforçada através do depoimento de uma campaigner da Survival International: 
Nós achamos que para alcançar mudanças positivas no mundo, você tem que influenciar, afinal, os governos, porque são eles que tomam as decisões políticas. E o melhor modo de fazer isso é através de pressões públicas. Mas nós fazemos isso de uma maneira pacífica e os brasileiros sabem disso. Nós somos respeitados por nosso trabalho porque nós trabalhamos seriamente. Nós somos respeitados porque sempre estamos tentando estar no campo. Eu vou lá e falo com muitas pessoas. É muito importante pesquisar e publicar depois de realizar uma rigorosa investigação dos fatos. Nós temos discutido com os governos, bem como com instituições como o Banco Mundial. Nós escrevemos cartas para as diferentes organizações responsáveis e somos muito respeitados pela precisão de nossas informações. É muito importante ter contato direto com a área, falar diretamente com os grupos indigenas e também com organizações brasileiras que trabalham no nivel das organizações de base.

Objetividade e profissionalismo sugerem um distanciamento em relação à proliferação de organizações ambientalistas que ocorreu nos anos 90. A “onda” ambiental decorrente da Eco-92 deflagrou um surto de criação de ONGs, intensificando um debate e até mesmo uma disputa entre campaigners de diferentes organizações. Tal debate pode ainda ser remetido a um período anterior à própria Conferência. Pertencente ao que ela identifica como uma "antiga geração" de militantes políticos do Reino Unido, a ex-campaigner da Oxfam relatou sua experiência nos debates políticos travados em meados dos anos 80 com aqueles identificados como a "nova geração de ativistas políticos na América Latina - os verdes":

Nos anos de 86, 87, 88, nós éramos poucos, os que realmente falavam sobre as questões sociais da Amazônia. As imagens da mídia aqui eram muito frustrantes e negativas. Só existia a floresta, o verde, os animais, as árvores, as queimadas (...) en fiquei muito crítica e irritada com esses documentários. Os indios não eram gente. Eles eram exóticos na floresta exótica: "nós devemos proteger os indios, os animais, as árvores, o rio etc.". Eles eram todos iguais. Era horrivel. Até hoje a mídia não reconhece que na Amazônia existem cidades, grandes cidades que surgiram nos anos 80 . Mas falar sobre cidades para o público aqui, no contexto da Amazônia, ecologia, desenvolvimento social - esqueça.

Ao mencionar a dimensão urbana subsumida aos interesses ecológicos no Reino Unido, a entrevistada revela as tensões subjacentes ao universo 
ANDRÉA Zhouri. ÁRVORES E GENTE NO ATIVISMO TRANSNACIONAL

dos campaigners. $\mathrm{Na}$ tendência "Gente", as campanhas referentes aos "povos da Amazônia" não se concentram apenas nas populações indígenas, mas compreendem também nesta categoria outros segmentos sociais, tais como os camponeses, os seringueiros, os trabalhadores rurais e urbanos, assim como os sem-terra. A Brazil Network, na qual os campaigners de "Gente" compartilham suas experiências e desenvolvem ações conjuntas, mobiliza também jornalistas, cineastas e acadêmicos envolvidos com o Brasil. Como dito acima, há uma certa clivagem entre os campaigners da tendência "Gente" e aqueles preocupados com as questões da biodiversidade na Amazônia. Existe, até mesmo, uma certa disputa em termos de legitimidade política entre aqueles que se percebem como "especialistas em Brasil" e militantes de longa data e aqueles considerados por estes como os "novos" atores políticos ambientalistas. Estes últimos, assim como os eventos ambientalistas tais como o Earth Summit (Cúpula da Terra), são acusados de terem "roubado e esvaziado a agenda social".

Todavia, se os campaigners de "Gente" foram bastante críticos aos ambientalistas por sua possível falta de sensibilidade social para com a Amazônia em meados dos anos 80 , estes últimos, por seu turno, tendem a perceber aqueles como meros filantropos. Assim, para os campaigners de "Árvores", a tendência "Gente" age no âmbito da "caridade", em bases muito localizadas, temporárias e fragmentárias - como agências de ajuda ao invés de apresentarem uma postura política transformadora em escala mais ampla. Diferenças e tensões à parte, a maioria dos campaigners pela Amazônia, no âmbito do que identifiquei como as três tendências no Reino Unido, expressa um entendimento dos processos globais e seus efeitos sobre as "populações locais". Os debates e disputas entre eles têm contribuído para a promoção de perspectivas e ações mútuas na esfera global, assim como influenciado políticas locais para a Amazônia e seus povos. 
Revista de Antropologia, São Paulo, USP, 2001, v. 44 nº 1.

\section{Conclusões}

Os campaigners britânicos envolvidos com o tema da floresta amazônica foram classificados a partir de três grandes tendências, metaforicamente chamadas de "Árvores", Árvores e Gente" e "Gente". Tais tendências foram sugeridas pelos marcadores discursivos que enfatizavam meio ambiente/biodiversidade, por um lado, e justiça social/desenvolvimento, por outro. Além disso, as marcas discursivas foram ainda remetidas às experiências pessoais de deslocamento dos campaigners, suas relações com o "local" e as justificativas para suas ações. Portanto, além das diferenças óbvias entre as ONGs ambientais e sociais, a idéia foi analisar os campaigners que, a rigor, elaboram e carregam consigo o ethos das ONGs, constituindo-se como importantes atores na formulação de um debate sobre a Amazônia.

Em resumo, todas as tendências identificadas aqui articulam "árvores e gente", ou seja, as questões da biodiversidade, justiça social, direitos humanos e desenvolvimento social. Tais aspectos são considerados afinal como harmonizados desde os anos 80, particularmente com o relatório Brundtland e seu conceito de desenvolvimento sustentável, este último consolidado ainda a partir do Earth Summit, em 1992.

Certamente, desde a época da conferência das Nações Unidas significativamente realizada no Brasil -, um discurso ambiental oficial que nascera na conferência anterior, em 1972, em Estocolmo, tem se estabelecido de forma hegemônica. No entanto, este discurso parece inscrever sociedade e desenvolvimento no bojo de uma concepção totalizante e evolucionista representada pelo conceito de crescimento econômico, enquanto transforma "natureza" em uma mera variável a ser "administrada" ou "gerenciada". Tais perspectivas globais têm sido impostas aos povos, sociedades e ambientes. A ideologia do "desenvolvimento" parece estar sendo revigorada pelo conceito de "desenvolvimento sustentável”, o qual também reivindica respeito pela biodiversidade assim como pela diversidade cultural. A fim de legitimar 
ANDRÉA Zhouri. ÁRVORES E GENTE NO ATIVISMO TRANSNACIONAL

este discurso oficial, as ONGs - antes portadoras de um contradiscurso - foram convidadas à "participação" e "parceria". Assim, as principais ONGs parecem ter acomodado seus discursos e práticas no interior desse panorama absorvente e institucionalizado.

A idéia de um "desenvolvimento sustentável” - significando vagamente a consideração das necessidades humanas para além das práticas conservacionistas - suscita posições consensuais quanto a seus princípios gerais. Contudo, um tal consenso não se sustenta diante de iniciativas e implementações práticas ${ }^{15}$. No que concerne perspectivas florestais, sobretudo na Amazônia, diferentes abordagens sobre desenvolvimento sustentável tornam difícil uma classificação simplificada e comum das ONGs em categorias como, por exemplo, organizações ambientalistas e conservacionistas. Trabalhar com "populações locais" ou "comunidades locais" tem se constituído numa reivindicação bastante popular. Diferentes posições no campo da militância "britânico-amazônica" são influenciadas pelas trajetórias pessoais e sociais dos campaigners, levando-os a partilhar formações discursivas que enfatizam um ou outro aspecto do campo. Procurei especificar regularidades e padrões discursivos através de uma discussão sobre as experiências dos campaigners enquanto viajantes, considerando ainda suas qualificações e histórias profissionais, a geração a que pertencem e o desenvolvimento de suas consciências políticas e envolvimentos com a Amazônia. Se as diferenças revelam um campo de militância e ativismo variado e dinâmico, elas também denunciam algumas limitações a serem superadas pelos campaigners entre si na GrãBretanha, assim como entre estes e seus parceiros brasileiros.

As duas tendências agrupadas na Forest Network-UK - "Árvores" e "Árvores e Gente" - parecem preocupadas, sobretudo, com o impacto das práticas econômicas globais em áreas florestais específicas, e têm sido efetivas em suas ações. Contudo, problemas a serem superados são resultantes da combinação de alguns fatores, dos quais destaco: a excessiva orientação técnica dos campaigners da tendência "Árvores" - um elemento necessário ao trabalho de contra-argumentação das ONGs em relação 
aos policy makers e interesses econômicos transacionais - que, aliada a uma perspectiva global centrada principalmente na biodiversidade, gera um distanciamento dos contextos sociais, históricos e culturais específicos da Amazônia, com a conseqüente redução da Amazônia à questão madeireira. Divorciada de seus contextos históricos, locais e regionais, a Amazônia é freqüentemente projetada na arena global como um mero ecossistema, sob a influência da economia global e suas forças políticas. Os padrões históricos de políticas para a região, assim como os diferentes sistemas sociais na Amazônia, tornam-se invisíveis ou são subsumidos a abstrações técnicas e pontuais sob o foco global. Assim, embora incorporem a defesa das "populações locais" no seu discurso (significando, principalmente, os povos indígenas), este permanece ainda como tópico secundário em suas considerações. As "parcerias" são estabelecidas com as ONGs brasileiras que podem corresponder às qualificações apropriadas, a saber, perícia técnica, habilidades lingüísticas e computacionais. Devido à grande demanda por informações em nível global, assim como um grau de dependência econômica das ONGs brasileiras em relação aos seus parceiros transnacionais, o escopo e papel das ONGs brasileiras no cenário das dinâmicas da agenda transnacional permanecem uma questão em aberto.

Os campaigners de "Árvores e Gente" são de uma geração mais antiga e menos técnica, estando espalhados pelas organizações e redes menores, em comparação com os campaigners de "Árvores". Observa-se nesse grupo uma tendência maior ao comprometimento político em relação a alternativas e perspectivas locais. Entretanto, a situação de intermediação entre as perspectivas "locais" e "globais" tende a ser mais pronunciada no caso destes campaigners. A maioria deles tem poucos recursos e depende da informação que os grupos maiores fornecem. Portanto, eles têm, em geral, um impacto limitado no estabelecimento das agendas políticas, embora sejam muito ativos e engajados nas campanhas em andamento. Em alguns casos, campaigners com longa história de militância podem influenciar na direção do debate geral entre 
ANDRÉA Zhouri. ÁRVORES E GENTE NO ATIVISMO TRANSNACIONAL

seus pares, provocando mudanças de posições mais afinadas com os princípios originais das ONGs, sobretudo, quando campaigners e campanhas tornam-se por demais subsumidos às negociações com setores privados e governos.

A tendência "Gente" revelou uma agenda política relacionada à defesa dos direitos humanos e justiça social. Estes campaigners estão agrupados na Brazil Network e não estão necessariamente envolvidos em campanhas ambientais. De modo geral, eles possuem uma formação na área de humanas e têm uma história de envolvimento com movimentos de esquerda no Brasil e na América Latina, em vez de um treinamento em silvicultura e história de ativismo no campo ambiental. Preocupações com as desigualdades sociais na América Latina podem sugerir, em alguns casos, uma certa proximidade com o discurso associado a uma perspectiva ideológica centrada no "desenvolvimento". Contudo, eles normalmente se opõem a projetos desenvolvimentistas que têm favorecido longamente as elites locais e o capital transnacional. Ao estabelecerem laços políticos e pessoais com as "populações locais" e adquirirem certa sensibilidade antropológica, estes campaigners apresentam-se como "latino-americanistas" ou "brasilianistas". Neste sentido, eles tendem a se imaginar como uma "voz mais autorizada" para falar sobre a região onde atuam. As preocupações éticas e políticas com "gente" - expressas na ênfase dada às desigualdades genéricas entre os hemisférios "sul" e "norte" - exigem uma abordagem prática nas campanhas. Isto sugere aos campaigners de "Árvores" uma despreocupação com a biodiversidade e a perspectiva ambiental "global", esta última entendida como aquela que mais firmemente questiona o "desenvolvimento" como um remédio contra a pobreza. Contudo, a agenda dos campaigners de "Gente" centra-se, a rigor, no apoio às organizações de base e movimentos sociais no Brasil. Um possível desafio para estes campaigners seria estabelecer um diálogo maior com as outras tendências, a fim de incorporarem preocupações ambientais às suas campanhas pelos povos da floresta, ao mesmo tempo em que 
Revista de Antropologia, São Paulo, USP, 2001, v. 44 nº 1.

incluam, cooperativamente, o componente social dentro do debate ambiental.

Finalmente, cabe notar que ambientalismo e etnicidade estão entrelaçados nas imagens da Amazônia construídas desde uma perspectiva britânica, assim como na arena transnacional mais ampla. $\mathrm{O}$ avanço da economia ocidental sobre as florestas tropicais e territórios dos povos indígenas tem conduzido a uma representação dos interesses destes povos para além da esfera tradicional local. Isto coincide com as reivindicações ambientalistas e preocupações com a biodiversidade e o meio ambiente global. Por outro lado, a ênfase nos povos indígenas como "povos da floresta", além de "naturalizá-los" no papel de guardiães da mata, pode eclipsar os demais segmentos sociais da Amazônia na esfera transnacional.

Nos anos 80, as queimadas na Amazônia eram as imagens mais difundidas pela mídia e pelas campanhas dos grupos ambientalitas. Desde os anos 90, é a exploração madeireira que tem ocupado as agendas da maior parte das ONGs. A campanha contra o comércio do mogno fez aumentar a necessidade de um trabalho especial que ligasse as ONGs sediadas no Brasil e na Inglaterra, na medida em que o Reino Unido é considerado um dos maiores importadores dessa madeira.

Sem dúvida, as Organizações Não-Governamentais têm se tornado uma das mais importantes forças políticas dos últimos anos, desafiando as tradicionais formas de organização política, como os Estados-Nação. As organizações ambientalistas estão entre estas e sua especialização técnica é uma ferramenta necessária em termos de gerenciamento e políticas ambientais. Todavia, um desafio futuro para os grupos ambientalistas será escapar do estado de assepsia provocado pelo distanciamento técnico-científico em relação aos contextos culturais locais que parece tê-los capturado, em última instância, na armadilha da atual agenda de mercado neoliberal. 
ANDRÉA Zhouri. ÁRVORES E GENTE NO ATIVISMO TRANSNACIONAL

\section{Notas}

1 Contudo, este não é o caso da "antropologizada que se torna antropóloga", nem tampouco trata-se de uma revanche do índio, do caboclo ou do ribeirinho - uma vez que eu não sou uma brasileira da Amazônia. Minha posição peculiar advém do fato de o Brasil ser um país que tem sido historicamente objeto de estudos por parte dos europeus e norte-americanos; enquanto a Inglaterra, em particular, tem epitomizado o Outro europeu para o Brasil. A peculiaridade de minha localização histórica e social é certamente relevante na presente discussão, e espero que isso fique claro nas páginas seguintes. Para discussão metodológica mais extensa, ver Zhouri (1998). Versões preliminares deste artigo foram apresentadas no III International Conference of Brazilian Studies Association (BRASA), Cambridge, UK, 7-10 September 1996, e na 22ª Reunião da Associação Brasileira de Antropologia (ABA), Brasília, 16-19 de julho de 2000. Uma versão em inglês sob o título "Pathways to the Amazon. British Campaigners for the Amazon Rainforest" foi publicada em THOMPSON, P. \& HUSSEY, S. (eds.), The Roots of Enviromental Conciousness, London, Routledge, 2000.

2 Ver, por exemplo, Eder (1996), Muller \& Morris(1992), Dalton \& Kuechler (1994), Edwards \& Hulme (1992; 1995), Eyerman \& Jamison (1991), Johnston \& Klandersman (1995), Lyman (1995), Mellucci (1989) entre outros. Para uma discussão crítica e uma perspectiva antropológica, ver Milton (1996).

3 A palavra campaigner não encontra tradução no idioma português. Ela será empregada no original em inglês, também para estabelecer o caráter profissional daqueles que trabalham para as ONGs, em oposição a ativistas ou militantes enquanto leigos ou sujeitos políticos não-profissionais. ONG é também um conceito problemático, como tem sido discutido por muitos autores (ver, por exemplo, Edward \& Hulmes, 1995). Embora reconhecendo as distinções entre Organizações Não-Governamentais, Organizações Voluntárias ou Organizações de Movimentos de Base, elas não serão discutidas nos limites deste artigo. Para a corrente proposta, usarei o termo ONG da maneira como é empregado pelos próprios campaigners, como parte de sua identidade política e cultural enquanto atores coletivos, independente de seu trabalho para as organizações altamente estruturadas e hierárquicas, tais como Friends of the Earth, Greenpeace, WWF ou pequenas organizações voluntárias como Reforest the Earth. Para uma análise sobre identidade coletiva, ver Melucci (1995). 
Revista de Antropologia, São Paulo, USP, 2001, v. 44 nº 1.

4 Uma análise mais aprofundada desta questão encontra-se em Zhouri (1998).

5 Por um período de mais de três anos, conduzi um trabalho de campo junto a diferentes setores da sociedade britânica envolvidos com a Amazônia brasileira. Um total de 67 entrevistas foi realizado com campaigners, jornalistas, produtores e diretores de filmes, pesquisadores, importadores de madeira (membros da Timber Trade Federation) e a empresa de cosméticos The Body Shop. Ao registrar os testemunhos dos campaigners, tentei seguir um método baseado em histórias de vida, mas encontrei dificuldades com esse modelo de entrevistas. Isso resulta de um conjunto de aspectos dos quais eu destacaria os já mencionados acima, como as imagens que os campaigners acreditam ter para os brasileiros, e as alegações de emotividade feitas aos ambientalistas pelo setor privado e governos aos quais se opõem. Outra possível explicação refere-se ao fato de que, como atores políticos e intelectuais, os campaigners não consideram suas experiências e sentimentos subjetivos como uma perspectiva relevante para o tipo de trabalho que realizam. No entanto, com o tempo e alguma persistência, pistas importantes surgiram e comprovaram frutífero o esforço de traçar os aspectos de suas trajetórias pessoais relacionados às causas que os movem e às organizações para as quais trabalham, assim como as especificidades dos engajamentos com a Amazônia e sua gente.

As entrevistas em profundidade seguiram um roteiro geral que foi dividido em dois blocos principais de questões. O primeiro bloco esteve preocupado com as trajetórias de vida em si, assim como com a emergência do envolvimento com questões ambientais, ONGs e a Amazônia. O segundo bloco teve uma preocupação temática mais específica relacionada às campanhas das ONGs, às relações entre ONGs na Grã-Betanha, assim como com seus parceiros no Brasil.

6 Para os conceitos de campo e discurso que inspiraram minha abordagem, ver Bourdieu (1993a; 1993b) e também Foucault $(1970,1972)$.

7 Isto tem ocorrido especialmente desde a campanha MDB (Multilateral Development Bank), no início dos anos 80, e foi consolidado posteriormente, durante o processo UNCED-92, através das relações mais próximas das ONGs com as agências sociais que já estavam se ocupando de tais assuntos. Para uma análise da campanha em torno das instituições multilaterais de desenvolvimento, lançada pelas entidades norte-americanas nos anos 80 e que suspenderam empréstimos do Banco Mundial para o programa de desenvolvimento na Amazônia, conhecido como Polonoroeste, ver Kolk (1996) e Arnt \& Schwartzman (1992). 
ANDrÉA ZHOURI. ÁRVORES E GENTE NO ATIVISMO TRANSNACIONAL

8 Esta posição crítica em relação ao conceito de "desenvolvimento sustentável" permeia as análises aqui apresentadas e foi detidamente tratada no artigo Zhouri (2001). Volto ainda a esta questão de forma mais explícita na conclusão deste artigo acompanhada de autores como Esteva (1992), Sachs (1992), Kirbby et al. (1995) e Lins Ribeiro (1991).

9 Para "discursos" e "deslocamentos", ver Clifford (1994). Para uma perspectiva sobre imperialismo e história do ambientalismo, ver Grove (1995) e também Arnold (1996).

10 Para uma discussão sobre as relações entre território, estado, economia e representação política no contexto da Amazônia, ver contribuições em D'Incao \& Silveira (1994).

11 Sobre o "saber local”, ver Geertz (1983).

12 Todas os grifos nesta e nas citações seguintes são meus, assim como a tradução das entrevistas do original em inglês.

13 Em Heart of Darkness, Conrad escreve: "Quando eu era jovem eu tinha uma paixão por mapas. Eu olhava por horas a América do Sul, a África, ou Austrália e me perdia nas glórias da exploração. Naquele tempo havia muitos espaços em branco na terra e quando eu via um que parecia particularmente convidativo no mapa (mas eles todos me seduziam) eu colocava meu dedo nele e dizia: quando eu crescer en irei lá. O Polo Norte foi um desses lugares, eu me lembro. Bem, en ainda não estive lá e eu não devo tentar agora. O glamour acabou" (1995: 21-2). Os grifos são meus.

14 Ver discussão em Zhouri (1998).

15 Para uma análise das tensões entre as dimensões social, ambiental e econômica no âmbito do FSC (Forest Stewardship Council), uma iniciativa de desenvolvimento sustentável que compreende a certificação de produtos florestais, ver Zhouri (1998). 
Revista de Antropologia, São Paulo, USP, 2001, v. 44 nº 1.

\section{Bibliografia}

ANDERSON, B.

1991 Imagined Communities: Reflections on the Origins and Spread of Nationalism, London, Verso.

ARNOLD, D.

1996 The problem of Nature. Environmentalism, Culture and European Expansion, Oxford, Blackwell.

ARN'T, R. \& SCHWAR'TZMAN, S.

1992 Um artifício orgânico. Transição na Amazônia e ambientalismo, Rio de Janeiro, Rocco.

\section{BECK, U.}

1992 Risk Society: Towards a New Modernity, London, Sage.

BOURDIEU, P.

1993a The Field of Cultural Production: Essays on Art and Literature, Cambridge, Polity Press.

1993b Outline of a Theory of Practice, Cambridge, Cambridge University Press.

\section{CLIFFORD, J.}

1994 The Predicament of Culture: Twentieth-Century Ethnography, Literature, and Art, Cambridge, Harvard University Press.

CONRAD, J.

1995

Heart of Darkness, London, Penguin Books. 
ANDRÉA ZHOURI. ÁRVORES E GENTE NO ATIVISMO TRANSNACIONAL

\section{DALTON \& KUECHLER}

1994 Changing the Political Order, Cambridge, Polity Press.

D'INCAO, M. A. \& SILVEIRA, I. M. DA (EDS.)

1994

A Amazônia e a crise da modernidade, Belém, MPEG.

EDER, $\mathrm{K}$.

1996

The Social Construction of Nature, London/New Delhi, Sage.

EDWARDS, M. \& HULME, D.

1992

Making a Difference, London, Earthscan

1995 Non-Governmental Organisations: Performance and Accountability - Beyond the Magic Bullet, London, Earthscan.

ESTEVA, G.

1992

"Development", in SACHS, W. (ed.), The Development Dictionary. A Guide to knowledge and power, London, Zed Books.

EYERMAN, R. \& JAMISON, A.

1991 Social Movements: A Cognitive Approach, Cambridge, Polity Press.

FEATHERSTONE, $\mathrm{M}$.

1990

Global Culture - Nationalism, Globalism and Modernity, London, Sage.

FOUCAULT, M.

1970 The Order of Things, New York, Random House.

1972 The Archaeology of Knowledge, London, Harper Colophon. 


\section{FRIEDMAN, J.}

1994 Cultural Identity and Global Process, London, Sage.

GEERTZ, C.

1983 Local Knowledge, New York, Basic Books.

GIDDENS, A.

1995 Beyond Left and Right, London, Polity Press.

GROVE, A.

1995 Green imperialism, colonial expansion, tropical island Edens and the origins of environmentalism. 1600-1860. Cambridge, Cambridge University Press.

GUHA, R. \& MARTINEZ-ALIER, J.

1997 Varieties of Environmentalism, London, Earthscan.

GUPTA, A. \& FERGUSON, J.

1992 "Beyond Culture: Space, Identity and the Politics of Difference", Cultural Anthropology, vol.7(1), Feb.

HARVEY, D.

1989 The Post-Modern Condition, Oxford, Blackwell.

JOHNSTON, H. \& KLANDERSMAN, B.

1995 Social Movements and Culture, London, UCL Press.

KECK, M. \& SIKKINK, K.

1999 Activists Beyond Borders. Advocacy Networks in International Politics, London/ Ithaca, Cornell University Press. 
ANDrÉA ZHOURI. ÁRVORES E GENTE NO ATIVISMO TRANSNACIONAL

KIRBY, J., O"KEELE \& TIMBERLAKE, L.

1995 The Earthscan Reader in Sustainable Development, London, Earthscan.

KOLK, A.

1996 Forests in International Environmental Politics. International organisations, NGOs and the Brazilian Amazon, Utrecht, International Books.

LASH, S., SZERSZYNSKI, B. \& WYNNE, B.

Risk, Environment \& Modernity: Towards a New Ecology, London:, Sage.

LINS RIBEIRO, G.

1991 "Ambientalismo e desenvolvimento sustentável. Nova ideologia/utopia do desenvolvimento", Revista de Antropologia, São Paulo,vol. 34: 59-101.

2000 "A condição da transnacionalidade", Cultura política no mundo contemporâneo, Brasília, UnB.

LYMAN, S.

Social Movements: Critiques, Concepts, Case-Studies, London, Macmillan

MACNAGHTEN \& URRY

1998

Contested Natures, London/New Delhi, TCS/Sage.

MELUCCI, A.

1989

Nomads of the Present, Philadelphia, Temple University Press.

1995

"The Process of Collective Identity", in JOHNSTON \& KLANDERSMAN, Social Movements and Culture, London, UCL Press.

MILTON, K.

1996

Environmentalism and Cultural Theory. Exploring the role of anthropology in environmental discourses, London, Routledge. 
Revista de Antropologia, São Paulo, USP, 2001, v. 44 nº 1.

MULLER, C., MCCLURG \& MORRIS, A.

1992 Frontiers in Social Movements Theory, New Heaven and London, Yale University Press.

PLACE, S. (ED.)

1993

Tropical Rainforests - Latin American Nature and Society in Transition, Jaguar Books on Latin America, n. 2.

ROBERTSON, R.

1992 Globalization, Social Theory and Global Culture, London, Sage.

SACHS, W. (ED.)

1992 The Development Dictionary: a guide to knowledge as power, London, Zed Books.

SAID, E.

1995 Orientalism: Western Conceptions of the Orient, London, Penguin Books.

THOMPSON, P.

1988 The Voice of the Past. Oral History, Oxford, Oxford University Press.

ZHOURI, A.

1998 Trees and People: an anthropology of British campaigners for the Amazon rainforest, PhD Thesis, University of Essex.

2000

"Pathways to the Amazon. British Campaigners in the Brazilian Amazon", in THOMPSON, P. \& HUSSEY, S. (eds.), The Roots of Environmental Counciousness, London, Routledge.

2001

"Transnational Campaigns for The Amazon. NGOs Strategies, Trade and Official Responses", Ambiente \& Sociedade, Campinas, n. 6. 
ANDRÉa ZHOURI. ÁrVORES E GENTE NO ATIVISMO TRANSNACIONAL

\begin{abstract}
Transnational activism is still an incipient topic within the field of Social Sciences. From an anthropological perspective, this article presents a contribution towards the understanding of global political and cultural processes taking place in the contemporary world. It focuses on the transnational activism around the Amazon Rainforest since the Amazon is one of the most important symbols of Western environmentalism. Most transnational NGOs dealing with the Amazon issue are based in the United Kingdom. They have been most active in the mahogany campaign, the campaign for the demarcation of indigenous lands, as well as in initiatives such as the FSC (Forest Stewardship Council) a certification scheme for forest products. This article analyses the campaigners social and political trajectories that led them engage with the Amazon in distinctive ways. It highlightes the tensions underlining social and environmental dimensions as discursive marks beyond institutional affiliations. Three major tendencies are revealed, as well as antagonistic global and local positions with significant consequences to environmentalism as a globalised field of communication, and the Amazon as both social and environmental space.
\end{abstract}

KEY WORDS: environmentalism, globalization, NGOs, Amazon Rainforest, trees, people.

Recebido em setembro de 2000. 